\title{
Drugs and Sexual Violence in the Conflict-Affected Region of Eastern DRC
}

\author{
Chelo Kpats Guyguy ${ }^{1}$, Ngabu Kilo Serge ${ }^{2}$ \\ ${ }^{1}$ College of Sociology, Central China Normal University, Wuhan, China \\ ${ }^{2}$ Department of International Law, Zhongnan University of Economies and Law, Wuhan, China \\ Email: guyguy.chelokpats@yahoo.com,sergekilo@hotmail.fr
}

How to cite this paper: Guyguy, C.K. and Serge, N.K. (2019) Drugs and Sexual Violence in the Conflict-Affected Region of Eastern DRC. Open Journal of Social Sciences, 7, 281-299.

https://doi.org/10.4236/jss.2019.73024

Received: February 11, 2019

Accepted: March 12, 2019

Published: March 15, 2019

Copyright $\odot 2019$ by author(s) and Scientific Research Publishing Inc. This work is licensed under the Creative Commons Attribution International License (CC BY 4.0).

http://creativecommons.org/licenses/by/4.0/

(c) (i) Open Access

\begin{abstract}
This study entitled "Drugs and Sexual Violence in the Conflict-Affected Region of Eastern DRC" analyses the relationship between the use of the cannabis drug and the commission of sexual violence in the Eastern region of the DRC affected by armed conflicts and gives an overview of the existing legal norms that regulate these problems, while proposing ways to eradicate these scourges. Indeed, it has been found that the abusive use of drugs (cannabis) in armed conflicts in Eastern DRC is one of the determining factors in the mass crime commissions of sexual violence. Likewise, it is assumed that the avowed objectives of destroying, annihilating, weakening, relocating the families of the victims, as well as the entire societies, have been the basis of the motives of the armed groups and of the other belligerents in order to gain military advantages on their enemies, by creating fear and mass leakage of the inhabitants before the insurgents. The magnitude of the atrocities has been commensurate with the need to conquer the territories in order to control the resources therein and to demand more conditions for the political negotiations. In order to understand this reflection, we have used two methods: on one hand, the empirical method is used to examine different random cases of the commission of sexual violence, thanks to the misuse of drugs, and on the other hand, we use an interdisciplinary approach to better understand this phenomenon, which saddens the population in eastern DRC. As the first pillar of all efforts to prevent sexual violence in armed conflict, we suggested strengthening the management of victims (medical and psychological monitoring, judicial assistance and empowerment of women and girls) and raising awareness of the population. Secondly, the prosecution of all the perpetrators (for detention and use of cannabis drugs as well as for commission of Sexual Violence) and the compensation of victims are considered as the second pillar. It is thus the responsibility of the Congolese Government to ensure the security of all its citizens, especially those in the conflict zones in East part of the DRC.
\end{abstract}




\section{Keywords}

Drugs, Sexual Violence and Conflict

\section{Introduction}

The Democratic Republic of the Congo is a vast country of Central Africa with its 87,230,014 inhabitants, its 450 tribal communities and with an area of nearly 2.5 million $\mathrm{km}^{2}$. It shares borders with nine other countries, namely: The Republic of the Congo, the Central African Republic, South Sudan, Uganda, Rwanda, Burundi, Tanzania, Zambia, and Angola.

Today, the Democratic Republic of the Congo still faces difficulties of all kinds. There have been for more than two decades in the DRC, wars and endless conflicts accompanied by mass rapes (Adama D., 2017) [1], mass deaths among civilians, internal and external displaced, looting of resources, insecurity on people and their property. Since start of the conflict, rape has become a widely used weapon which has gradually entered communities.

Sexual violence can happen to anyone, regardless of age, race, income level, ethnicity, religion, sexual orientation, and education level. However, certain vulnerabilities or risk factors contribute to sexual violence victimization and perpetration; consuming alcohol and drugs is among those factors (Crowell, NA., et al., 1996). ${ }^{1}$ Such as sexual violence, drug abuse, alcohol and drug addiction cross all the borders of society and are among the main issues in all communities in the eastern provinces of the DRC and across the nation.

The DRC (not to be confused with its neighboring smaller size country, the Republic of the Congo, located at west and usually designated simply Congo) plays a little active role in regional efforts to curb drug trafficking, there is usually evidence of little will for combating intensive expansion of this activity within its own borders. The impact of the war, corruption and the lack of financial means are a hindrance to the implementation of repression, through well trained and well paid agents, able to conduct effective investigations.

Enforcement of the drug laws is not considered as priority and the country is suspected to close its eyes on the major part of production and trafficking due to corruption at the highest legislative and government level. However, senior Congolese officials participated in the conference of Heads of Law Enforcement at the national level in the fight against the illicit drug trafficking (HONLEA), which was held in Windhoek, Namibia in October 2009, a sign of their crescent commitment in international efforts.

In 2011 the National Geographic reported that rebel forces had cleared protected areas, critical habitat for the endangered of gorillas in Virunga National Park to plant marijuana, and several Rangers had been gunned down by mili${ }^{1}$ https://en.wikipedia.org/wiki/Factors_associated_with_being_a_victim_of_sexual_violence\#cite_no te-Crowell_NA_1996-10. 
tiamen that eager to protect their lucrative investment. There is very little information about the rates of arrest and the nature of the sentences imposed for crimes related to drugs in the DRC. Despite a misapplication of laws, drug trafficking, including cannabis, is considered a capital crime in the DRC. However, authorities do not systematically impose the death penalty. It is unclear how many 330 to 500 inmates currently on death row are there for drug-related offenses.

In the case of a Ugandan citizen arrested in possession of five kilograms of opium in Azanga, a platform of trade of a province in the East of the DRC, Congolese judges preferred to impose a sentence of imprisonment of a "number of years". Rather than the death penalty, perhaps in order to find a friendly solution to a situation that is likely to be the cause of international tension.

Cannabis is grown throughout the country, with production concentrated in the provinces of Kasai, Bandundu, Equateur and Bas-Congo. There are no statistics on the area under cultivation or yields of cannabis, and the only information available on the seizures often comes from other countries where Congolese citizens are regularly arrested while they try to make of the smuggling of cannabis and other drugs.

The terms drug-facilitated sexual assault or alcohol-facilitated sexual assault have been coined to describe a subset of sexual assault. Some of the drugs that could be used to facilitate a sexual assault, including alcohol, can cause unconsciousness, impair the victim's memory, or limit their decision-making ability. In some cases, the substances are given to the victims surreptitiously, which may decrease their ability to identify a dangerous situation or to physically resist the perpetrator. Alcohol is the most common drug used to facilitate sexual assaults Juhascik, M.P., et al., (2007, pp. 1396-1400) [2].

Unlike some other drugs, alcohol is legal, readily available, and socially acceptable if not socially encouraged in some settings. Researches with convicted rapists, community samples of sexual assault perpetrators and victims/survivors, and college student perpetrators and victims/survivors consistently find that approximately half of the sexual assaults are associated with alcohol use by the perpetrator, victim, or both. Researchers consistently have found that approximately one-half of all sexual assaults are committed by men who have been drinking alcohol, with estimates ranging from $34 \%$ to $74 \%$ Abbey, A., et al., (2003) [3]. There is widespread anecdotal evidence indicating that the majority of rape and sexual assault cases being reported to law enforcement involve alcohol use by the victim, the defendant, or both.

Sociologically speaking, and as affirms Wood, E. J., (2009) [4], poverty can be identified as one of the reasons for massive commission of violence, including sexual violence by armed groups. Poverty features in their explanations in different ways constitute an obstacle to their having sex, compelling them to use force, and as a source of frustration and anger that is manifested in an urge to harm and destroy. However, perpetrators often use substances such as alcohol or drugs to incapacitate their victims in order to facilitate a sexual assault (Prevention and Responses 2009). Moreover, the involvement of the military in drug 
trafficking is systematic, it is far from exceptional. With the goal: the personal enrichment of the officers and the strengthening of the military potential of the committed troops.

Our main goal in this discussion is to take a look at the original and refreshing knowledge on drug norms and sexual violence as well as development security in eastern DRC in post-conflict. Thus, as a sociologist, the following fundamental questions will be of our thinking:

Why do actors (fighters, police, and military) resort to drugs for the commission of sexual violence?

How the drug influences the actors in the commission of sexual violence?

What are the existing measures to prevent or repress these scourges?

To better understand this thinking, we used two methods: Firstly, the empirical method is used to examine different random cases of perpetration of sexual violence due to drugs and, secondly, the interdisciplinary methodological analysis is to better understand the reality of this phenomenon in eastern DRC. Thus, we have rightly referred to the theories developed by some authors to support this study.

Feminists and activists began to draw these connections between sexual assault and patriarchy. In her 1975 book, Against Our Will, Susan Brownmiller argued that rape is a tool of intimidation used by men to control and ensure the subordinate status of women. These theories eventually coalesced into the current understanding of sexual assault, namely, that rape and other forms of sexual assault are acts of violence, not acts of sexual desire: Rape is an act of violence which uses sex as a weapon (Brownmiller, S., 1975) [5].

Rape is motivated by aggression and by the desire to exert power and humiliate. Just a wife battering had to be taken out of the privacy of the home and criminalized in order to effect any change, rape must be taken out of the sexual realm and placed where it rightfully belongs in the domain of violence against women (Patricia, W. E., 1992) [6].

Although sexual desire is sometimes relevant to issues of sexual assault, perpetrators are motivated by a desire for power and domination. "Like other forms of torture, it is often meant to hurt, control and humiliate, violating a person's innermost physical and mental integrity (Radhika, C., 1995) [7].

Apart from the introduction and conclusion, the architecture of our study is based around the four main points:

- Drugs for Sexual Practices;

- The impact of drugs on the actors of sexual violence;

- Measures of prevention and repression against perpetrators of sexual violence;

- Prevention and repression against the illicit use of drugs (cannabis).

\section{Discussion}

\subsection{Drugs for Sexual Practices}

In contexts of armed conflict, sexual violence is often accompanied by torture 
(blows, electric shocks, mutilation, suffocation, physiological positions by suspension, extended isolation, hard work, etc.). And go after women became a way to terrorize all the civilian population to flee and to occupy their field, force them to submit, but also punish them for supposedly supporting the enemy forces.

\subsubsection{Psycho-Physiological Drug Effects}

As Dawgert, S., (2009, p. 22) [8] demonstrates, there are a number of possible linkages between sexual violence and substance abuse. The substances may have been used voluntarily or involuntarily before the assault, during the assault, or as an adaptation strategy in response to the trauma suffered whether by the author or the victim. Some of the drugs that could be used to facilitate a sexual assault, including alcohol, can cause unconsciousness, impair the victim's memory, or limit their decision-making ability (Negrusz, Juhascik \& Gaensslen, 2005; Scalzo, 2007 cited by Dawgert, S., 2009, p. 29).

In the same vein, it was argued at The Hague Conference that the Drugs can either stimulate the ardor of the warrior in battle or make him unaware of the danger, or erase, after the battle, the pain of the injury or the extreme tension caused by the clashes, particularly when they take the form of close combat. This aspect of the drug conflict report remains present today, especially in Africa where most fighters lack very sophisticated weapons. The drug is systematically provided to child soldiers to enable them to withstand the stress of combat (Sénat du Canada, 1999, p. 5) [9].

Different rebel groups may sometimes conflict for control of areas of production or delivery of the drug routes. When regular troops enter in conflict against the rebels for that same control, in this case, the drug is at the center of the belligerency at the expense of their ideological interests and causes the criminalization of the insurgents and it pushes the security forces to fight. In this case, the drugs became a part of the extension of the conflict.

Buchanan (1996) argues that socio-political, cultural, psychological and biological variables must be considered to explain the presence of violence, including one of a sexual nature. Indeed, the presence of physical abuse, neglect, crime problems and alcohol and drugs of the parents is also frequently reported by sex offenders (Delphine, C.V., et al., 2003) [10]. According to many writings, consumption of hemp "cannabis" for its psychotropic effects would have been imported from Africa to Brazil by black slaves. It has subsequently extended towards North to Mexico to finally reach them.

During colonization, culture, detention, consumption, smoking and sale of hemp "cannabis" were prohibited by a Special Act which should be current. But like the moonshine (considering), the population continued to use clandestinely. It's the urbanization that has moved the use of cannabis from the village to our cities. From this moment, consumption has spread to young, first as an act of rebellion against colonial oppression, before taking the dimensions we know.

Foregoing, it turns clear that consumption of drugs "cannabis" enormously 
plays a role on the psychology of the fighters so well that the leaders of armed groups and or even armed forces resort to this practice, and sometimes impose on the elements under their commands to consume the cannabis drug to help them commit deviant acts during the armed conflict.

At the same time, the drug cannabis is part of war strategies before the opponent (the drugged fighters do not make neighborhood and destroy everything on their passages).

\subsubsection{Rapes and Drugs as War Weapons}

According to the WHO, violence can be defined as "deliberate use or the threat of the deliberate use of physical force against oneself, another person or against a group or community likely to cause trauma, death, moral injury, a sore development or a deficiency. The forms of sexual violence perpetrated in the contexts of armed conflict are multiple and varied.

We're talking about rape as a weapon of war or as a method of war when it is scheduled by a politico-military authority and used strategically by one of the parties to a conflict to humiliate, destroy, weaken, subject, hunt or destroy the other. It is generally mass rapes (perpetrated on many victims), multiple rapes (a victim is assaulted repeatedly) and collective (the victim is attacked by several assailants), frequently committed in public, accompanied by the most often beatings and kicking.

Rape as a weapon of war is a form of attack against the enemy. It characterizes the conquest and the degradation of women embodying the opposing cultural identity, the humiliation of the men in charge of their protection but powerless to defend them as well as the shame of the captured fighters. Committed with the deliberate attempt to sow terror, infamy, and the seeds of social rejection, it is a weapon of psychic destruction of a community. In addition to the desire to sow fear and shame, rape can be used to contaminate the rivals and spread disease as the virus of HIV/AIDS (Josse, E., 2013) [11].

In armed conflicts, rape can serve these purposes but also be exploited for reasons more treacherous as polluting the ethnicity of a community. For example, during the conflict in the former Yugoslavia, Serb fighters used rapes and forced pregnancies to pervert the "race" of their enemy and destroy the future of the Bosnian community. Similarly, in the East of the Democratic Republic of the Congo, coming from Rwanda the Hutu fighters use this strategy to force the Congolese women to give birth and carry children of their cultural identity, for the purpose of civil settlement in the region they militarily occupy.

In addition, some rapes may be seen as rewards granted to veterans by the military authorities. Supervisors sometimes allow, or even encourage their troops to commit rapes on the civilian population as recompense of the services rendered, exalt their bravery and boost their morale. Similarly, after a victory, it is not uncommon that the winners violated girls and women of the vanquished considered spoils of war, and sometimes, they sexually assaulted men intending to humiliate them. 
In the DRC, the fighters are generally young and sexually active, unmarried or separated from their families (lacking emotional and sexual outlets), summarily educated (ignorance of the law) and exempt from social control from their community of origin, sometimes embedded in unstructured and unframed combat units. In addition, they enjoy virtually guaranteed impunity (silence of the victims, tolerance of the authorities about sexual assault, disorganization of the police and judicial systems, etc.) and they frequently consume substances that diminish their ability to resonate (alcohol adulterated, drugs and cannabis).

It should be noted that girls and women are abducted by fighters and sequestered in their camp. In some cases, they are considered to be the wife of one man; in others, they are sex slaves of the troupe. In addition to sexual services, they are responsible for domestic, agricultural and military tasks. Sexual slavery is sometimes organized and planned by the military authorities. Thus, girls and women are kidnapped to satisfy the sexual needs of the armed forces. They are prostitutes in barracks or in brothels under military control.

To this end, to satisfy their sexual urges, armed men, both fighters as civilians, take advantage that gives them their weapons to demand sexual favors from women of the opposing community, or even of theirs. Rape by armed men has become a "weapon of war" used in a massive and systematic way by all parties to the conflict, with impunity. Accordingly, this crime is commonplace throughout the territory, including in areas of relative stability.

According to the Special Reporter of the United Nations on violence against women, who visited in the DRC in July 2007, allegations of raping committed by members of the DR Congo Armed Forces (FARDC) and the Congolese National Police (PNC) were numerous. There were also more and more rapes committed by civilians. Although its 2017 report seems more precise, in terms of the more or less verifiable figures on all cases of sexual violence, the fact remains that for multiple reasons (fear of complaint, the stigmatization of the victims, the fact that most of the victims are in inaccessible areas or the fact that some victims do not survive the violence), it is impossible to precisely estimate the number of victims of rapes and other sexual violence in the DRC. The only certainty, their magnitude is huge (UN Report S/2017/249, 2017, p. 11) [12].

Let us say their authors, militias, insurgent, rebellious, but also members of the Congolese army, enjoy quasi-absolute impunity. Because of this culture of impunity, sexual violence is being trivialized and it develops in the rest of the country, including in the capital, Kinshasa. So sexual violence constitutes a weapon of humiliation, subjugation and terror as it aims to destroy community ties. In this respect, it fulfills one of the conditions of the crime of genocide.

As already mentioned, all this sexual violence was committed, in most cases, thanks to the consumption of the drug cannabis. The use of the latter (in the diversity of its species) is one of the elements determining the Commission of the crime of sexual violence so that it is part of the crime as such. Where, just like sexual violence, the drug cannabis also becomes a strategic asset of war and therefore a weapon of war. From this point of view, the cannabis drugs and sex- 
ual violence become inseparable in the search for the evidential elements of the crime.

\subsection{The Impact of Drugs on the Actors of Sexual Violence}

These causal influences are probabilistic, not deterministic. Most drug users are not otherwise criminally active, and the vast majority of drug using incidents neither causes nor accompanies other forms of criminality. Nevertheless, drugs clearly play an important causal role in violent and property crime. These causal influences are contingent, not unconditional. There is little evidence that drug use per se directly causes people to become aggressive in some direct and unconditional manner or that criminality per se causes someone to use drugs. That drug use can causally influence criminality does not necessarily implicate the psychopharmacological properties of the drug (Robert, J. M., et al., 2003) [13].

Note that the drug cannabis use in the commission of sexual violence generates mental trauma and its attendant symptoms (PTSD, anxiety disorders, depression, behavioral, etc.). It causes an alteration of cognitive abilities (disorders of memory and concentration, inability to think, etc.).

As to family level, sexual violence frequently causes family problems. Thus, drug cannabis, sexual violence, and sexual abuse are part of the usual arsenal of torturers. At the social level, sexual violence results in an overall reduction in psychosocial functioning. Feelings of self-worth and human dignity are violated by the write-downs and humiliation, submission to the aggressor, the transgression forced values and personal taboos.

Ultimately, in the East of the DRC, the proportion of women abandoned by their spouses because of rape drug is high. They are often stigmatized by the inhabitants of the village, those who should bring them comfort as they are living in the same environment. They have given the name of the armed group that had kid-coated, raped them by calling Muka Bahutu, in Mashi, language of the Shi people which means: a woman of Hutus, for example. The territory of the Bashi is particularly concerned by these events, hence this reference to this ethnic group and the fact for mushi women to be treated constitute kinds of underestimation, stigmatization or social exclusion. All this pushes their families to reject them or to be forced by their husbands to leave the home with their children.

Most of the women attended to the death of their spouses who couldn't support to see their wives tortured, seeking to defend or protect them, but unfortunately, they were executed on the spot. Other armed groups take pleasure in torturing their husbands before their wives to destroy the morale of these women in order to destroy them completely. For most of the armed groups, the choice of the place where they commit rape is not trivial. In $61 \%$ of cases, rape is committed in the workplace: in the field, to the market. The aim is to destroy this woman who is doing everything to meet the needs of his family. Rapists know that now women will be afraid to return to his place of field work because 
of the trauma. This fear to go to this place also affects the other members of the family ...

According to Rubuye, S. S., et al., (2015), the choice of rape and rape by vaginal and anal way were not chosen randomly. The number of rapes committed by armed groups is more important than those committed by other social groups. This confirms the strategy of "rape as a weapon of war".

From the above, it was found that the armed groups need to inflict on enemies such a terrible sentences as described above; this drives them to resort to the use of powerful means to achieve these objectives, including making strong liquor (very alcoholic) and local drugs (from plants such as cannabis hemp and other plants) or imported (bricks ...). Thus, they cancel all fear and all compassion for victims in order to destabilize them, break up their families and/or make them disappear as a whole people.

\subsection{Measures of Prevention and Repression against Perpetrators of Sexual Violence}

According to Wood et al. (2010), soldiers and officers interviewed are in agreement with the international community on the need for punishment and emphasize countering impunity as a preventive measure. In all interviews, we asked the soldiers to identify the measures needed to end or curtail sexual violence, they suggested the introduction of severe punishments as the most pressing measure, followed by training for the militaries (often the second most important measure identified by ex-FAC) and improving living conditions (often third). In all the interviews contexts, soldiers underscored that adequate punishment for the crimes they and their colleagues commit are the only way to put a stop to them. Most often they have linked the need for punishment to the need to impose order and discipline. ${ }^{3}$

Since the second half of the past century, it has developed around the world a new form of crime on a large scale, most often justified by the interests of economic, social and political. This is, particularly about sexual violence.

In this section we will consider, on the one hand, the mechanisms for the repression of sexual violence at national level, and on the other hand, the existing mechanisms at international level, in particular the ICC.

The wars of 1996 and 1998 in the Democratic Republic of the Congo have made the already deplorable economic situation worse and caused millions of victims which are most exposed and covered but they still are cruelly hit by the crimes of all categories. These victims have been reached in their dignity, their physical and moral integrity, but also in their lives. Thus, such acts cannot remain unpunished in the future. Faced with the need to prevent and severely repress the offenses related to sexual violence and ensure a systematic support of the victims of these offenses, it has proved compelling to revisit some provisions ${ }^{2}$ http://dx.doi.org/10.1016/j.sexol.2015.06.003.

${ }^{3}$ https://doi.org/10.1177/0032329208329755 (Published by Elisabeth Jean Wood, March 1, 2009). 
of the Criminal Code (Criminal Congolese Act, 2006) [14].

Article 14 (bis): in accordance with articles 48 and 49 below, Public prosecutor requires ex officio doctor and psychologist, in order to assess the state of the victim of sexual violence and to determine the appropriate care as well as to assess the significance of the damage suffered by him/her and his or her further aggravation.

Article 14 (ter): By way of derogation, as regards offenses relating to sexual violence, the following rules apply to the taking of evidence:

1) In no case may consent be inferred from the words or conduct of a victim where the victim's ability to freely give valid consent has been altered by the use of force, cunning, narcotics, threat or coercion or in a coercive environment;

2) Consent cannot, under any circumstances, be inferred from the silence or lack of resistance of the victim of the alleged sexual violence;

3) The credibility, good repute or sexual availability of a victim or witness can in no way be inferred from their previous sexual behavior;

4) Evidence of prior sexual behavior of a victim of sexual violence cannot exonerate the accused from criminal liability.

Article74 (bis): The Public prosecution officer or the sexual assault judge shall take the necessary steps to safeguard the safety, physical and psychological well-being, dignity and privacy of the victims or any other person Involved.

In this respect, behind closed doors is delivered at the request of the victim or the public prosecutor.

By virtue of this amendment, the consent of the victim might be invoked as a means of defense. However, the accused cannot invoke it if the victim has been the subject of pressures that made him reasonably to fear of being abused or that someone else is (Mohammed, A., 2010) [15].

The text does not specify whether the complainant must be present at this first hearing in view of the severity, relevance and credibility of the evidence against the accused. And it seems to us that judges could exploit this silence to avoid unnecessary trauma to the most vulnerable victims when they demand their presence.

According to the report of the Secretary-General of the United Nations on the situation in the DRC presented in March 2007 at the Security Council, the justice sector in need of operational capabilities. It has never been independent and has never had the means to prosecute offenses and enforce the decisions of the courts. The low wages compounded corruption, and few citizens have access to legal assistance. Less than $60 \%$ of the 180 required courts of the first instance have been implemented, the laws are outdated and judicial facilities and prisons are extremely dilapidated. Although military courts have recently made a small number of decisions relating to violations of human rights, there is near-total impunity in the Democratic Republic of the Congo.

The following paragraphs try to account for this remarkable jurisprudential work in the field of repression of sexual violence. 
The 2006 Constitution establishes the basis for the fight against impunity on sexual violence and sets out in its article 15: "Public authorities shall ensure the elimination of sexual violence. Without prejudice to the international treaties and agreements, any sexual violence on any person, with the intention of destabilizing him, breaks up a family and makes a whole people disappear is set up as a crime against humanity punishable by law".

Moreover, in terms of the Rome Statute of the International Criminal Court, its ratification by the DRC allows the repression of organized sexual violence and massively committed in the context of crimes against humanity or war crimes such as rape, sexual slavery, forced prostitution, forced pregnancy, forced sterilization or any other form of sexual violence of comparable gravity. It can also include other provisions provided for in this Rome Statute such as the modes of liability, protection of victims and witnesses or rights of the defense.

Let's take a look at the Act $\mathrm{N}^{0} 06 / 018$ of $20^{\text {th }}$ July 2006 amending and supplementing the Congolese criminal code. Faced with the need to prevent and severely punish the offenses relating to sexual violence, the Act $\mathrm{N}^{0} 06 / 018$ of 20 July 2006 seeks to amend and supplement the Congolese Criminal Code by "the integration of the rules of international humanitarian law" relating to the offenses of sexual violence. Thus, this law, on the one hand, redefined the offences of rape, forced prostitution, pimping and attack in more modest terms. On the other hand that law increased the scale of the applicable sentences while enriching the Congolese criminal law by adding twelve new offences of sexual violence (see Articles 170 to $174 \mathrm{n}$ of the law 06/018 of July 20, 2006, supplementing and amending the Congolese penal code. These offenses are: sexual harassment, sexual slavery, forced marriage, sexual mutilation, zoophilia, deliberate infection transmission ...).

The above mentioned Act is also expected as a right to a fair trial. It should be noted that the principle of the right to a fair trial applies to all phases of the criminal procedure, i.e. both pre-jurisdictional phase of the investigation and instruction, during the jurisdictional, during the drafting phase of the judgment and its execution. These rules are derived from the fundamental principles set out in the 2006 Constitution and from international conventions ratified by the DRC.

The prevention and crackdown on the perpetrators of sexual violence are provisions that policy measures must be based on a good understanding of the problem, its causes and the circumstance in which it occurs. In the DRC, the laws cited above are not enough sufficient for fighting against this phenomenon.

However, we wish on this point the following:

- Measures in favor of the population in areas of armed conflict (securing, sensitizing against sexual violence and medical, psychological and economic care, ... of victims);

- Measures against the actors of sexual violence (Eradication of the armed groups, arrest and judgment of the perpetrators in accordance with the crimi- 
nal law);

- Democratization, social justice and the solution to the problems of sexual violence.

Strengthening the role of the State and good governance in the Congo is necessary to combat sexual violence. The Democratic Republic of Congo is, today became a State party to the Treaty of the International Criminal Court, the Rome Statute, when it signed the Treaty on 8 September 2000, and ratified on 11 April 2002, which gave to the ICC jurisdiction over war crimes, crimes against humanity and genocide committed on Congolese territory or by Congolese citizens after $1^{\text {st }}$ July 2002 (date of the entry into force of the Rome Statute).

However, the ICC is competent in cases where the Government is not willing or able to investigate or to pursue these crimes. It is, as well as the investigation of the ICC on crimes committed in the DRC began only after the Congolese Government had formally referred the situation in the East of the country to the ICC on April 19, 2004.

Therefore, the Prosecutor of the ICC has decided to focus its investigation on the situation in Ituri Province due to the seriousness of the crimes committed during the conflict in that Province. It is as well that a series of initiatives are undertaken in the world to combat sexual violence in general, including those related to the use of drugs as the case in the DRC.

The Prosecutor of the International Criminal Court (ICC) opened two investigations into the most serious crimes in the region of Ituri since $1^{\text {st }}$ July 2002, date of its jurisdiction on the Congolese territory. These have resulted in the arrest and transfer to The Hague, of four former warlords suspected perpetrators of crimes of war and crimes against humanity. It's Thomas Lubanga and Bosco Ntaganda, respectively President of the Union of Congolese Patriots (UPC) and Chief of Staff in the UPC armed militia, Germain Katanga, the President of the Force of Patriotic Resistance in Ituri (FRPI), and Mathieu Ngudjolo, leader of the Front of Nationalists and Integrationists (FNI). Besides, Thomas Lubanga, all others were prosecuted for crimes related to sexual violence. However, Mathieu Ngudjolo had been released for lack of evidence, but Germain Katanga and Bosco Ntaganda was sentenced.

The ICC is not intended to judge all the crimes committed in a country. The criminal policy of the Prosecutor of the ICC is to conduct surveys and targeted trials, covering only a "sample" of crimes committed in a certain region, in a certain period. The Prosecutor will pursue only a very limited number of criminals: the highest officials. In addition, the ICC works on the principle of complementarity with national justice when it does not have the will or the ability to judge the perpetrators of the most serious crimes. Therefore, in principle the priority of pursuit belong to Congolese justice to judge the perpetrators of violations of international humanitarian law and human rights. But it is failing. That's why the International Federation for Human Rights (FIDH) considers essential that the pursuit of sex crimes being part of the whole of the criminal 
policy of the Prosecutor of the ICC (FIDH, 2018) [16].

In the same line, the European Union and the Government of Canada support the efforts undertaken in the framework of the United Nations in order to prevent and punish sexual crimes, including by providing support to the work of MONUSCO and the efforts of the Government of the DRC.

Indeed, it is important here to point out that the DRC, in its efforts to combat impunity for international crimes, including those related to the sexes, had taken the initiative to amend certain laws to adapt them to the Rome statute of the ICC of which it is a party. In particular, concerning Articles 7, 8, 23 - 25 of the Rome Statute, the definition given by the Congolese Military Criminal Act to the crime against humanity was no longer identical to the Rome Statute (Art. 165 to 172 of the CPM).

To that, given the complexity of the phenomenon of sexual violence, several additional ways of solutions are conceivable. This prompted us to formulate the following recommendations: towards the ICC:

The Office of Prosecutor of the ICC must:

- Set up a structure that allows integrating a strategy for prioritization of investigation and prosecution of sex crimes directly linked to the pursuit;

- Integrate systematically a strategy of prosecution of crimes in all investigations and trials;

- Implement the provision contained in paragraph 9 of article 42 of the Rome Statute, by recruiting one or several specialists in the field of law on SGBV;

- strengthen the mandate of the Unit of Gender-Specific Violence and Children, so it attends the investigations division as well as the other divisions of the Office of the Prosecutor, and also expand the number of members of the staff of this unit so that sex crimes are duly taken into account in all the activities of the Prosecutor;

- Direct and regular consultations between the Office of the Prosecutor and the victims of sex crimes.

Towards the ICC Administration as whole:

- Regularly conduct campaigns of awareness and information (including the rights of victims) affecting particularly the victims of sex crimes;

- Conduct regular campaigns to give specific information to the victims of sex crimes and to institutions and civil organizations working with the victims of crimes;

- Be particularly pro-active in support of programs of assistance to victims of sex crimes, including victims of sex-related drug crimes.

\subsection{Prevention and Repression against the Illicit Use of Drugs (Cannabis)}

In many developing States, leaders, senior administration and local authorities are sometimes themselves involved in drug trafficking. But the Governments of Northern veil the face to avoid compromising their economic or strategic interests. There is no corrupts without corruptors (Sénat Canada, Op. cit. 1999, p. 23). 
During colonization, cultivation, possession, consumption and sale of hemp to smoke were prohibited by the special law which should be in force so far. But like denatured alcohol (Lotoko in Congolese dialect), the population continued to consume it clandestinely. Indeed, it is the urbanization that has shifted the use of hemp from the village to our cities. From this moment, his consumption has spread to young people, first as an act of rebellion in the face of colonial oppression, before taking the dimensions that we know. ${ }^{3}$

In 1957, Jean Jacques Kande confessed in a resounding article that "one smokes hemp", to taunt the colonial power. But until then the use of hemp was very limited because of good family and school supervision. As for the hard drug (cocaine), it intruded into the Congo through the port city of Matadi. The young people of this city were ahead of the rest of the young people of the other Congolese cities. ${ }^{4}$

Today, the cannabis is frequently used as a cigarette by many young people in Kinshasa. Yet everyone knows that its sale is illegal. In some parts of the city called "Kuzu" i.e. "corridors", hemp smokers isolate themselves to buy or sell this product, commonly called "Diamba", "noix", "Bangi" or simply "Matiti". More serious, among them, there are also police officers, military, or even some local authorities. ${ }^{5}$

According to the survey results (interviews) conducted by Joëlle Botamba (on September 24, 2018) on the reasons for smoking hemp despite the legal ban, most of the interviewees including a policeman found at the site, claim that hemp allows them to be fit and to do their job better. When they take it, it is the most enduring and allows them to think well and avoid nonsense.

In fact, the use of hemp is illegal in the DRC. In the past, the Ordinance-law of 22 January 1903 approved by Decree of 1 March 1903 laying down measures against the use of smoking hemp prohibited in article 1 "the cultivation, sale, transport, possession and consumption of hemp for smoking".

At the same time, this Ordinance, in its Article 3, provides the following penalties for offences:

- A fine of one hundred to thousand francs and a penal servitude of fifteen days to one year or one of these sentences only;

- The destruction of crops and confiscation of seized hemp;

- Seizure and confiscation of the instruments used to smoke hemp or to consume hemp in any way whatsoever.

Thus, the said Ordinance-law jointly condemns the offenders and the village chiefs if the latter has not taken precautions to prohibit the use of hemp and its cultivation.

Also, Ordinance No. 72/005 of 14 January 1972 strengthening the protection of precious substances and the cocaine of which stipulates in article 1 that "the ${ }^{3}$ http://www.mbokamosika.com/article-12980921.html.

${ }^{4}$ Idem.

${ }^{5}$ https://habarirdc.net/reglementer-legaliser-consommation-cannabis-chanvre-rdc-diamba-noix-kin shasa/. 
smuggling and detention without legal title of cocaine shall be punished by more than 10 years of penal servitude". In addition, Ordinance No. 83/178 of 28 September 1983 establishing the Commercial Police Commission instructs the latter to enforce the regulations by carrying out all necessary investigations and by submitting the possession of certain toxic products such as hemp, cocaine or narcotics to a particular authorization. ${ }^{6}$

Lastly, it is important to note that the DRC is a party to the Convention against illicit traffic in Narcotic Drugs and Psychotropic Substances of 1988.

From the foregoing, we find that the Congolese regulations on the fight against the illegal use and trafficking of drugs and other narcotic and toxic substances have not evolved so much, while the trafficking and use of cannabis have widespread over time in large cities, as in Kinshasa, and more exponentially, in areas of armed conflict in Eastern DRC. This expansion of trafficking and drug use has a direct impact on the proliferation of sexual violence in the East of the DRC, where members of armed groups and armed forces are using hemp and other drugs to nullify human consciousness when it comes to conducting attacks on civilian populations in enemy areas.

In these circumstances, it becomes very difficult to enforce the aforementioned legal texts in these areas of conflict where State authority is struggling to exercise. Thus, there is almost total impunity for traffickers as well as for drug users who are sometimes also perpetrators of sexual violence in these conflict zones.

In the end, in order to eradicate these scourges, the Congolese state is called upon to take substantial measures, among other things:

- The priority dismantling of armed groups which control certain areas of the country;

- The restoration of state authority in re-conquered areas, formerly occupied by armed groups;

- The strengthening of the judiciary to prosecute all violations of legal texts in the field of trafficking and the use of drugs;

- Strengthening national regulations on trafficking and illicit drug use to adapt it to the current realities of the country;

- The strengthening of border security and judicial cooperation with neighboring States in the fight against illicit trafficking and in use of drugs, in particular cannabis.

\section{Results and Suggestions}

It is clear from this study that members of groups and armed forces sometimes use cannabis to commit sexual violence. This euphoria substance leads to habituation and a state of stupor.

The abusive consumption of drugs (cannabis) in armed conflict in the East of

${ }^{6} \mathrm{http} / / /$ afrique.kongotimes.info/sante/5474-trafic-stupefiants-congo-intensifie-lutte-contre-detentio n-cocaine.html. 
the DRC is one of the determinant factors in mass sexual violence crimes commissions. Indeed, it was found that the stated objectives to destroy, weaken and dislocate families of victims, as well as entire societies, have been the basis of motivations of armed groups and other belligerents in order to gain military advantages on their enemies, by creating fear and mass leakage of residents in front of insurgents, as mentioned previously.

The scale of the atrocities has risen to be the need to conquer the territories in order to control the natural resources and demand more conditions for political negotiations. The central Government repeatedly declined to these rebel groups by accessing their wishes, so that sexual violence has been trivialized because they constituted, from this point of view, a springboard to access to certain benefits or power-political and economic. In this situation, the victims are delivered to their sad fates, in absence of effective mechanisms for prevention and repression of these crimes.

From the above, our research on the sexual violence due to the misuse of drugs (cannabis) pushes us to make proposals on the following specific points. There is a need to strengthen the capacity of the national police and army to secure the population in areas of conflict (logistical and financial support). Another point is allowing justice to pursue with priority all cases of sexual violence and all cases of detention and misuse of drugs (we know that on a number of cases of sexual violence, only very few have been brought to justice, and of this number very few have led to the conviction of the perpetrators and reparation for the victims). The financing and independence of the judiciary should be strengthened to combat impunity in the courts of justice, and to guarantee effective compensation for the benefit of the victims. At the same time, there is a need to broaden the possibilities for mobilizing more resources in order to support the holistic care of victims because of the massive and systematic consequences of sexual violence suffered, in one hand, and in the other hand, insisting on the changes in mentality to operate at the level of the traditional and religious leaders, prior to the legislative changes needed.

Other proposed solutions include multiplying awareness campaigns against sexual violence and the misuse of drugs cannabis, creating frames of expression for victims so that they speak out against the violence suffered. Commissions of follow-up and evaluation of activities against sexual violence and against the misuse of drugs cannabis should also be created. Finally the dismantlement of all drugs trafficking networks in favor of armed groups or populations is very important.

In fact, this reflection shows that military conflicts in the East of the DRC create a triple trauma, often indelible to individuals, family and community. However, further studies should be conducted to assert or confirm these allegations.

\section{Conclusions}

One of the main lessons learned from this study is the fact that abusive use of 
cannabis drugs is a permanent danger as a cause of sexual violence that continues to occur on a large scale in the conflict areas of Eastern DRC. Thus, the importance attached to this study lies, on the one hand, in the fact that it strives to highlight these scourges and to attract the attention of both the national, regional and international community. On the other hand, it advocates ways of ending drug-related sexual violence in times of armed conflict, considered a legitimate threat to sustainable peace and security in the region.

Reflecting on the ways to prevent these scourges and to remedy, on the one hand, and to deal with a worsening of the problem, on the other hand, it was considered important to encourage accountability to justice of all the perpetrators (traffickers and abusive consumer of the drug cannabis which are sometimes also authors of sexual violence) and to strengthen preventive measures in this area to discourage future abuses.

To this end, we suggested strengthening the global support of victims (medical and psychological follow-up, judicial assistance and empowerment of women and girls) and the awareness of the population as the first pillar of efforts to prevent sexual violence in armed conflict. Then the lawsuits of all authors (for the detention and using drug cannabis as well as for the commission of sexual violence) and the compensation of victims are to be considered as the second pillar. This is why it is up to the Congolese Government to ensure the security of all citizens, particularly those in conflict areas in the East of the DRC.

Moreover, considering on the one hand that in addition to the cultivation of cannabis, there is indeed a significant traffic of this substance as well as other drugs between the DRC and its neighbors, whose traffic nodes include the waterway connecting Brazzaville to Kinshasa, the Ndjili International Airport in Kinshasa and the port of Matadi, and on the other hand, the fact that Congolese traffickers are also responsible for sending drugs to black markets in Africa and in various Western countries, it becomes very urgent to combat these cross-border trafficking in these narcotics by means of the reduction of their demands. This implies the eradication of armed groups and the dismantling of mafia drug distribution networks in exchange for money and arms. To this end, it is clear that border security must be strengthened and a more effective system of control should be put in place to stop the influence of the authorities in the face of border services in the East part of the country and everywhere else. Police cooperation with neighboring countries must also be seen as a means of combating such trafficking.

Thus, several other recommendations have been formulated in an attempt to end this phenomenon including the creation of Commissions of follow-up and evaluation of control activities against sexual violence and against the illicit use of drugs cannabis.

Furthermore, as part of this process, we have limited our research on the impacts of the cannabis drugs in the commission of mass sexual violence in times of conflict; this is for including and establishing a clear and important distinction between sexual violence unrelated to the abuse of drugs and armed con- 
flicts. The various recommendations should subject to future studies in order to verify the empirical relevance. Such a recommendation does not exclude the study "of another variable" promising that would allow a better understanding of this complex phenomenon. Future research by exploring this issue could also address some methodological problems often present in studies of the drug cannabis and sexual violence, such as those concerning the criminal organization drug trafficking in this part of the DRC.

\section{Acknowledgements}

We acknowledge Pr. DARRELL IRWIN, Dean, College of Sociology for his constructive feedback on improving earlier drafts of this paper.

\section{Conflicts of Interest}

The authors declare no conflicts of interest regarding the publication of this paper.

\section{References}

[1] Adama, D. (2017) Report of the Secretary-General on Conflict-Related Sexual Violence.

[2] Juhascik, M.P., Negrusz, A., Faugno, D., Ledray, L., Greene, P., Lindner, A., Haner, B. and Gaensslen, R.E. (2007) An Estimate of the Proportion of Drug-Facilitation of Sexual Assault in Four U.S. Localities. Journal of Forensic Sciences, 52, 1396-1400. https://doi.org/10.1111/j.1556-4029.2007.00583.x

[3] Abbey, A., Clinton-Sherrod, A.M., McAuslan, P., et al. (2003) The Relationship between the Quantity of Alcohol Consumed and the Severity of Sexual Assaults Committed by College Men. Journal of Interpersonal Violence, 18, 813-833. https://doi.org/10.1177/0886260503253301

[4] Wood, E.J. (2009) Armed Groups and Sexual Violence: When Is Wartime Rape Rare? Politics and Society, 37, 131-161. https://doi.org/10.1177/0032329208329755

[5] Brownmiller, S. (1975) Against Our Will Men, Women and Rape. Ballantine Books, New York City, New York, 475.

[6] Patricia, W.E. (1992) Violence Prevention Today. Rape, 1-11.

[7] Radhika, C. (1995) Sexual Violence against Refugees: Guidelines on Prevention and Response. 56.

[8] Sarah, D. (2009) Substance Use and Sexual Violence: Building Prevention and Intervention Responses, the Pennsylvania Coalition against Rape, 2009, 112 p.

[9] Sénat du Canada (1999) Conflits, drogues et activités mafieuses, Contribution aux travaux préparatoire de la conférence de La Haye sur la Paix, 11-16 mai 1999, La Haye, 1-26.

[10] Delphine, C.V. and Cyr, M. (2003) The Transmission of Sexual Violence: Description of the Phenomenon and Ways of Understanding. Child Abuse \& Neglect, 27, 489-507. https://doi.org/10.1016/S0145-2134(03)00038-3

[11] Josse, E. (2013) Torture and Sexual Violence in the Armed Conflict, Close Ties. A Torturer, World 9.

[12] (2017) Report of the UN Secretary-General on Conflict-Related Sexual Violence. 11.

[13] Robert, J.M. (2003) Research on Drugs-Crime Linkages: The Next Generation. To- 
ward a Drugs and Crime Research Agenda for the 21st Century, Washington, DC, 65-95.

[14] Congolese Criminal Code and Congolese Criminal Procedure Code as Modified by "the 2006 Acts on Sexual Violence."

[15] Mohammed, A. (2010) A Few Contributions to the Tribunals, Ad Hoc and International Including the ICTR, to the Fight against Sexual Violence against Women during the Genocide and the Arms 1 Conflicts. Vol. 10, 787-827.

[16] FIDH (2018) The Rome Statute at Twenty (1998-2018): 10 Challenges to an Effective and Independent International Criminal Court. 8. 